\title{
Risiko Gangguan Pendengaran pada Neonatus Hiperbilirubinemia
}

Gatot Irawan Sarosa, Alifiani Hikmah Putranti, JC Susanto

Bagian Ilmu Kesehatan Anak RSUP Dr Kariadi, Fakultas Kedokteran Universitas Diponegoro

Latar belakang. Menurut data WHO tahun 2007, diperkirakan prevalensi gangguan pendengaran pada populasi penduduk Indonesia 4,2\%, salah satu penyebab gangguan pendengaran adalah hiperbilirubinemia pada neonatus. Identifikasi dini gangguan pendengaran dan intervensi optimal pada usia enam bulan pertama dapat mencegah gangguan bicara dan bahasa, prestasi akademik, hubungan personal sosial, dan emosional pada anak.

Tujuan. Membuktikan dan menganalisis risiko hiperbilirubinemia terhadap terjadinya gangguan pendengaran pada neonatus.

Metode. Dilakukan penelitian kohort pada 36 neonatus dengan hiperbilirubinemia di RS Dr. Kariadi, Maret 2009 - Maret 2010, terdiri dari 18 kelompok kasus dengan kadar bilirubin indirek $\geq 12 \mathrm{mg} / \mathrm{dl} \mathrm{dan}$ 18 kelompok kontrol dengan kadar bilirubin indirek $<12 \mathrm{mg} / \mathrm{dl}$. Subyek penelitian dipilih menggunakan metode consecutive sampling. Dicatat data klinis, laboratorium, dilakukan tymphanometri, OtoAcustic Emission (OAE) dan Brainstem Evoked Response Audiometry (BERA) pertama serta OAE dan BERA tiga bulan kemudian. Analisis dilakukan dengan uji Chi-square, uji Mc Nemar dan uji t tidak berpasangan.

Hasil. Kejadian gangguan pendengaran pada pemeriksaan BERA awal sebanyak 9 kasus (25\%) dan 3 kasus $(8,3 \%)$ pada pemeriksaan BERA kedua, secara statistik tidak bermakna ( $p>0,05)$. Pada pemeriksaan BERA awal, rerata kadar bilirubin indirek tidak berbeda bermakna $(\mathrm{p}>0,05)$ antara neonatus dengan gangguan pendengaran $14,18 \pm 6,289 \mathrm{mg} / \mathrm{dl}$ dan neonatus tanpa gangguan pendengaran $(11,29 \pm 2,995) \mathrm{mg} / \mathrm{dl}$. Nilai risiko relatif (RR) 2,0 (p>0,05; 95\% CI 0,6-6,8), namun secara statistik tidak bermakna.

Kesimpulan. Kejadian gangguan pendengaran pada neonatus dengan hiperbilirubinemia adalah $25 \%$. Kadar bilirubin indirek $\geq 12 \mathrm{mg} / \mathrm{dl}$ belum dapat disimpulkan sebagai faktor risiko gangguan pendengaran pada neonatus dengan hiperbilirubinemia. Sari Pediatri 2010;12(4):222-7

Kata kunci: Neonatus hiperbilirubinemia, gangguan pendengaran

\footnotetext{
Alamat korespondensi:

Dr. Gatot Irawan Sarosa, Sp.A, Bagian Ilmu Kesehatan Anak RSUP Dr. Kariadi Semarang, Jl. Dr. Sutomo 18 Semarang. E-mail: gt_irawan@ yahoo.com.
}

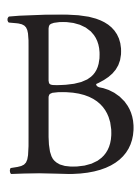

erdasarkan Data Survei Kesehatan Indera Pendengaran di tujuh propinsi tahun 19941996 menyebutkan prevalensi gangguan pendengaran dan ketulian di Indonesia adalah $16,8 \%$ dan $0,4 \% .{ }^{1}$ Menurut data WHO tahun 2007, prevalensi gangguan pendengaran pada populasi penduduk Indonesia diperkirakan 4,2\%. Maka ber- 
dasarkan data tahun 2002 apabila jumlah penduduk Indonesia 221.900.000, 9.319.800 penduduk Indonesia diperkirakan menderita gangguan pendengaran. ${ }^{2}$

Hiperbilirubinemia merupakan salah satu penyebab gangguan pendengaran. ${ }^{3}$ Kegagalan dalam mendeteksi anak-anak dengan gangguan pendengaran kongenital maupun didapat dapat menyebabkan gangguan bicara dan bahasa, prestasi akademik yang kurang, gangguan hubungan personal sosial dan gangguan emosional. Identifikasi dini gangguan pendengaran dan intervensi yang optimal pada usia 6 bulan pertama dapat mencegah gangguan-gangguan tersebut. ${ }^{4}$

Test Brainstem Evoked Response Audiometry (BERA) dapat digunakan sebagai deteksi dini gangguan pendengaran karena dapat dipergunakan pada segala usia, tidak tergantung pada kondisi bayi sedang tidur atau bangun dan merupakan alat deteksi yang efektif untuk mengukur abnormalitas telinga bagian tengah dan dalam. BERA menggunakan "click stimulus" untuk menggambarkan respon elektrik dari batang otak dengan pengukuran melalui elektrode permukaan. Sensitivitas BERA dilaporkan 100\% dan spesifisitas 97\%-98\%..$^{5}$ Peneliti memilih BERA karena keunggulan karakteristik sederhana, efektif serta mudah diterapkan. ${ }^{6}$ Tujuan penelitian membuktikan dan menganalisis risiko hiperbilirubinemia terhadap terjadinya gangguan pendengaran pada neonatus.

\section{Metode}

Penelitian observasional dengan rancangan kohort dilakukan di Bagian Ilmu Kesehatan Anak FK UNDIP/ RS Dr. Kariadi Semarang pada periode bulan Maret 2009 sampai dengan bulan April 2010. Subyek penelitian adalah neonatus hiperbilirubinemia yang dirawat di Ruang Bayi Sehat, Bangsal Bayi Risiko tinggi (BBRT) RS. Dr. Kariadi Semarang pada periode Maret 2009 - April 2010.

Kriteria inklusi adalah kadar bilirubin total $\geq 5$ $\mathrm{mg} / \mathrm{dl}$, lahir cukup bulan, berat badan lahir $\geq 2500$ gram, bayi ikterik, orang tua/wali bersedia anak diikutsertakan dalam penelitian, dan dapat mengikuti penelitian sampai tiga bulan. Kriteria eksklusi adalah riwayat penyakit yang dapat mempengaruhi fungsi pendengaran, misalnya meningitis, ensefalitis., hipoxic ischemic encephalopathy, klinis dicurigai infeksi kongenital TORCH, menderita asfiksia berat saat lahir, hasil pemeriksaan menunjukkan adanya tuli kon- duktif, bayi dengan kelainan malformasi kongenital. Pemeilihan subyek penelitian menggunakan metode consecutive sampling.

Pengumpulan data dimulai dengan memilih bayi yang memenuhi kriteria inklusi, kemudian dicatat data klinis dan laboratorium (khususnya kadar bilirubin total dan bilirubin indirek) selama perawatan serta lamanya perawatan. Orang tua pasien diberi informasi tentang penelitian dan selanjutnya diminta kesediaan menandatangani formulir informed consent. Pada pasien dilakukan pemeriksaan skrining timpanometri dan OAE untuk menyingkirkan tuli konduktif, selanjutnya pemeriksaan BERA dilakukan apabila sesuai dengan kriteria inklusi untuk mendeteksi adanya gangguan pendengaran. Pemeriksaan timpanometri dan BERA dilakukan oleh ahli audiologi tanpa melihat status riwayat hiperbilirubinemia pasien. Gangguan pendengaran ditentukan berdasarkan hasil pemeriksaan BERA. Pasien selanjutnya diminta kembali tiga bulan berikutnya untuk menjalani pemeriksaan timpanometri dan BERA kedua oleh ahli Audiologi yang sama melakukan pemeriksaan BERA.

Uji hipotesis dengan menggunakan uji $\chi^{2}$, uji ini dipilih oleh karena variabel terikat dan variabel bebas berskala kategorial. Besarnya pengaruh dinyatakan dengan besaran risiko relatif (RR) untuk analisis bivariat. Uji multivariat regresi logistik tidak dilakukan oleh karena variabel tidak memenuhi syarat untuk multivariat. Nilai $R R>1$ dengan 95\% interval kepercayaan dan rentang kepercayaan tidak mencakup angka 1, berarti variabel tersebut dianggap sebagai faktor risiko. Batas kemaknaan adalah apabila $\mathrm{p} \leq 0,05$. Analisis data dilakukan dengan program komputer.

Protokol penelitian telah mendapat persetujuan dari Komisi Etik Penelitian Kedokteran FK UNDIP/RSDK No.19/EC/FK/RSDK/2009 dan mendapat persetujuan Direktur SDM dan Pendidikan RSUP Dr. Kariadi Semarang No. DL.00.02.Diklit.158. Penanganan semua pasien (neonatus hiperbilirubinemia dan neonatus yang mengalami gangguan pendengaran) sesuai dengan protokol penanganan bayi hiperbilirubinemia dan gangguan pendengaran di Bagian Perinatologi RSUP Dr. Kariadi.

\section{Hasil}

Didapatkan subyek 48 bayi, 6 orang tua/wali bayi menolak mengikuti penelitian dan 6 bayi drop out 
karena tidak melakukan pemeriksaan OAE dan BERA kedua. Total subyek penelitian adalah 36 neonatus yang memenuhi kriteria penelitian sebagai sampel dengan kadar bilirubin total $\geq 5 \mathrm{mg} / \mathrm{dl}$, terdiri atas 18 neonatus dengan kadar bilirubin indirek $<12 \mathrm{mg} / \mathrm{dL}$ sebagai kelompok kontrol dan 18 neonatus dengan kadar bilirubin indirek $\geq 12 \mathrm{mg} / \mathrm{dL}$ pada periode yang sama sebagai kelompok kasus.

Tabel 1 menunjukkan rerata berat badan lahir pada kelompok kasus adalah lebih berat dibanding pada kelompok kontrol. Berdasarkan jenis kelamin bayi, pada kelompok kasus lebih banyak bayi berjenis kelamin laki- laki, sebaliknya pada kelompok kontrol lebih banyak berjenis kelamin perempuan. $(\mathrm{p}=0,003)$. Umur subyek penelitian pada saat pemeriksaan pendengaran pertama kelompok kasus adalah lebih tua dibanding kelompok kontrol. Hal yang sama juga tampak pada umur subyek penelitian pada saat pemeriksan pendengaran kedua. Berdasarkan cara lahir sebagian besar subyek penelitian pada kelompok kasus dan kontrol lahir secara sectio secaria, selanjutnya adalah lahir spontan dan paling sedikit adalah lahir dengan ekstraksi vakum.

Berdasarkan pemeriksaan OAE awal pada kelompok kasus dan kontrol dijumpai masing-masing 1 neonatus

Tabel 1. Karakteristik neonatus pada kelompok kasus dan kontrol

\begin{tabular}{|c|c|c|c|}
\hline \multirow[b]{2}{*}{ Karakteristik neonatus } & \multicolumn{2}{|c|}{ Kelompok kadar bilirubin indirek } & \multirow[b]{2}{*}{$\mathrm{p}$} \\
\hline & $\begin{array}{c}\text { Kelompok kasus } \\
\mathrm{n}=18\end{array}$ & $\begin{array}{c}\text { Kelompok kontrol }{ }^{\bullet} \\
\mathrm{n}=18\end{array}$ & \\
\hline Berat lahir (gram, rerata \pm SB) & $3080,6 \pm 509,94$ & $3036,1 \pm 514,44$ & $0,6^{*}$ \\
\hline \multicolumn{4}{|l|}{ Jenis kelamin bayi, n (\%) } \\
\hline Laki-laki & $14(77,7)$ & $5(27,7)$ & \\
\hline Perempuan & $4(22,3)$ & $13(72,3)$ & $0,003^{£}$ \\
\hline Usia saat pemeriksaan pertama (hari, rerata $\pm S B$ ) & $7,6 \pm 5,96$ & $4,1 \pm 1,21$ & $0,09^{*}$ \\
\hline Usia saat pemeriksaan kedua (hari, rerata \pm SB) & $103,6 \pm 13,33$ & $101,9 \pm 11,32$ & $0,7^{\S}$ \\
\hline \multicolumn{4}{|l|}{ Cara lahir, n (\%) } \\
\hline Spontan & $7(38,8)$ & $4(22,2)$ & \\
\hline Sectio caesaria & $9(50)$ & $12(66,5)$ & \\
\hline Ekstraksi vakum & $2(11,2)$ & $2(11,2)$ & $0,5^{¥}$ \\
\hline $\begin{array}{l}\text { Keterangan } \\
{ }^{*} \text { Uji Mann-Whitney } \\
{ }^{*} \text { Uji Kolmogorov-Smirnov }\end{array}$ & $\begin{array}{c}\S \text { Uji } t \text {-tidak } \\
\text { •Kelompok kon }\end{array}$ & $12 \mathrm{mg} / \mathrm{dl})$ & \\
\hline
\end{tabular}

Tabel 2. Hasil pemeriksaan gangguan pendengaran

\begin{tabular}{|c|c|c|c|}
\hline \multirow{2}{*}{$\begin{array}{l}\text { Hasil pemeriksaan gangguan } \\
\text { pendengaran }\end{array}$} & \multicolumn{2}{|c|}{ Kelompok kadar bilirubin indirek } & \multirow[b]{2}{*}{$\mathrm{p}^{\mathrm{F}}$} \\
\hline & $\begin{array}{c}\text { Paparan }(+)^{*} \\
\mathrm{n}=18\end{array}$ & $\begin{array}{c}\text { Paparan }(-)^{* *} \\
\mathrm{n}=18\end{array}$ & \\
\hline Hasil pemeriksaan OAE awal, n (\%) & & & 1,0 \\
\hline Refer & $1(5,6)$ & $1(5,6)$ & \\
\hline Pass & $17(94,4)$ & $17(94,4)$ & \\
\hline Hasil pemeriksaan OAE kedua, n (\%) & & & 0,5 \\
\hline Refer & $0(0)$ & $2(11,2)$ & \\
\hline Pass & $18(100)$ & $16(88,8)$ & \\
\hline Hasil pemeriksaan BERA awal, n (\%) & & & 0,4 \\
\hline Gangguan pendengaran $(+)$ & $6(33,3)$ & $3(16,7)$ & \\
\hline Gangguan pendengaran (-) & $12(66,7)$ & $15(83,3)$ & \\
\hline Hasil pemeriksaan BERA kedua, $\mathrm{n}(\%)$ & & & 1,0 \\
\hline Gangguan pendengaran $(+)$ & $1(5,6)$ & $2(11,1)$ & \\
\hline Gangguan pendengaran (-) & $17(94,4)$ & $16(88,9)$ & \\
\hline
\end{tabular}


dengan hasil OAE refer (ada kelainan), sedangkan hasil pass (tidak ada kelainan) pada kelompok kasus dan kontrol masing-masing 17 neonatus. Hasil uji statistik menunjukkan tidak ada perbedaan bermakna pada distribusi hasil pemeriksaan OAE antara kedua kelompok $(\mathrm{p}=1,0)$. Hasil pemeriksaan OAE kedua menunjukkan pada kelompok kasus tidak dijumpai hasil refer dan seluruhnya (18 neonatus) adalah pass, sedangkan pada kelompok kontrol dijumpai 2 neonatus dengan hasil refer dan 16 neonatus dengan hasil pass. Hasil uji statistik menunjukkan perbedaan tersebut adalah tidak bermakna $(\mathrm{p}=0,5)$ (Tabel 2).

Berdasarkan pemeriksaan BERA pada saat awal pada kelompok kasus lebih banyak yang didiagnosis menderita gangguan pendengaran dibanding pada kelompok kontrol. Namun hasil uji statistik menunjukkan perbedaan tersebut adalah tidak bermakna $(p=0,4)$. Pada pemeriksaan BERA kedua jumlah neonatus yang menderita gangguan pendengaran justru lebih banyak pada kelompok kontrol dibanding kelompok kasus, namun hasil uji statistik menunjukkan perbedaan tersebut adalah tidak bermakna $(\mathrm{p}=1,0)($ Tabel 2).

Didapatkan kejadian gangguan pendengaran pada pemeriksaan BERA awal 9 kasus (25\%) dan kejadian gangguan pendengaran pada pemeriksaan BERA kedua 3 kasus (8,3\%). Kadar bilirubin indirek subyek penelitian berdasarkan hasil pemeriksaan BERA awal dan kedua tertera pada Tabel 3 .

Tabel 3 menunjukkan kadar bilirubin indirek pada subyek penelitian dengan gangguan pendengaran berdasarkan hasil pemeriksaan BERA awal maupun BERA kedua adalah lebih tinggi dibanding subyek penelitian tanpa gangguan pendengaran. Hasil uji statistik menunjukkan perbedaan tersebut tidak bermakna. Pada pemeriksaan BERA awal, kejadian

Tabel 3. Kadar bilirubin indirek berdasarkan hasil pemeriksaan BERA awal dan kedua

\begin{tabular}{lcc}
\hline Hasil pemeriksaan & $\begin{array}{c}\text { Rerata } \pm \mathrm{SB} \\
(\mathrm{mg} / \mathrm{dl})\end{array}$ & $\mathrm{p}$ \\
\hline Pemeriksaan BERA awal & & \\
- Gangguan pendengaran (+) & $14,18 \pm 6,289$ & \\
- Gangguan pendengaran (-) & $11,29 \pm 2,995$ & $0,2^{9}$ \\
Pemeriksaan BERA kedua & & \\
- Gangguan pendengaran (+) & $12,33 \pm 5,506$ & \\
- Gangguan pendengaran (-) & $11,99 \pm 4,127$ & 0,9 \\
\hline
\end{tabular}

'Uji Mann- Whitney gangguan pendengaran lebih banyak dijumpai pada kelompok kasus, sedangkan kejadian tidak ada gangguan pendengaran lebih banyak pada kelompok kontrol, namun hasil uji statistik menunjukkan perbedaan tersebut tidak bermakna $(\mathrm{p}=0,4)$. Nilai risiko relatif (RR) adalah 2, yang berarti kelompok kasus dengan hiperbilirubinemia indirek $(\geq 12 \mathrm{mg} /$ dl) mempunyai risiko untuk mendapatkan gangguan pendengaran dua kali lebih besar dibandingkan kelompok kontrol namun tidak bermakna secara statistik.

\section{Pembahasan}

Bayi lai-laki pada kelompok kasus lebih banyak dari pada bayi perempuan, sebaliknya pada kelompok kontrol lebih banyak berjenis kelamin perempuan. $\mathrm{Hal}$ ini sesuai dengan pendapat Tioseco $\mathrm{dkk}^{7}$ bahwa mekanisme pengaruh jenis kelamin terhadap peningkatan bilirubin belum jelas, faktor yang diduga mempengaruhi metabolisme bilirubin pada neonatus laki- laki adalah kromosom $Y$ yang menyebabkan peningkatan metabolisme dan terjadinya defisiensi maturasi sistem enzim pada pembentukan, metabolisme, dan eliminasi serum bilirubin, terutama pada neonatus berat lahir rendah akan tetapi hal ini masih menjadi perdebatan para ahli.

Ditemukan rerata kadar bilirubin indirek pada kelompok gangguan pendengaran awal lebih tinggi dari pada kelompok tanpa gangguan pendengaran. Boo $\mathrm{dkk}^{8}$ dalam penelitiannya menemukan gangguan pendengaran pada neonatus aterm berbeda bermakna apabila dihubungkan dengan usia saat terjadinya hiperbilirubinemia dan hiperbilirubinemia berat yang memerlukan tranfusi tukar.

Boo $\mathrm{dkk}^{8}$ juga menemukan bahwa semakin dini usia timbulnya hiperbilirubinemia meningkatkan risiko terjadinya gangguan pendengaran yang diduga karena kerentanan saraf auditori terhadap toksin bilirubin yang rendah pada neonatus aterm usia dini. Hasil yang berbeda dilaporkan oleh Ahlfors dan Parker bahwa probabilitas hasil abnormal pada BERA meningkat sesuai dengan peningkatan kadar bilirubin indirek dan bermakna secara statistik. Hal ini disebabkan penelitian tersebut menggunakan parameter pemeriksaan kadar bilirubin indirek bebas dan pemeriksaan BERA dilakukan dalam rentang waktu satu hingga empat jam setelah pemeriksaan kadar bilirubin indirek. ${ }^{9}$ Pada penelitian 
ini kadar bilirubin indirek bebas tidak diperiksa karena keterbatasan fasilitas di RS Dr. Kariadi Semarang serta pemeriksaan BERA yang tidak dapat dilakukan segera setelah dilakukan pemeriksaan kadar bilirubin indirek dan sebelum dilakukan fototerapi ataupun tranfusi tukar sesuai dengan tata laksana di Bagian Perinatologi.

Kejadian gangguan pendengaran pada pemeriksaan BERA awal terjadi pada 9 kasus (25\%), 6 neonatus dengan gangguan pendengaran pada kelompok kasus dan 3 neonatus dengan gangguan pendengaran pada kelompok kontrol. Hasil yang sama ditemukan oleh Boo dkk, bahwa kejadian gangguan pendengaran pada neonatus hiperbilirubinemia $25 \%$, sedangkan jumlah kejadian gangguan pendengaran pada neonatus hiperbilirubinemia yang berbeda disebutkan oleh Sharma dkk ${ }^{6} 73,3 \%$, dan Ahlfors dkk 9\%. Perbedaan tersebut mungkin dilaporkan karena penentuan jumlah subyek penelitian. Boo $\mathrm{dkk}^{8}$ menggunakan parameter pemeriksaan laboratorium bilirubin total pada 128 neonatus aterm. Sharma dkk menggunakan parameter pemeriksaan laboratorium bilirubin total pada 60 neonatus aterm sedangkan Ahlfors $\mathrm{dkk}^{9}$ menggunakan pemeriksaan bilirubin indirek bebas pada 44 neonatus dengan usia gestasi $>34$ minggu.

Pemeriksaan BERA kedua menunjukkan jumlah pasien dengan gangguan pendengaran berkurang. Hal ini dapat disebabkan karena semua pasien dengan gangguan pendengaran pada pemeriksaan BERA awal ternyata menjadi normal pada pemeriksaan BERA kedua. Ditemukan pula tiga pasien yang mengalami gangguan pendengaran pada pemeriksaan BERA kedua dengan rincian sebagai berikut.

Satu pasien dengan hasil pemeriksaan OAE kedua pass akan tetapi hasil BERA kedua mengalami gangguan pendengaran ringan walaupun pada pemeriksaan OAE dan BERA awal tidak mengalami gangguan pendengaran. Gangguan pendengaran ini diduga sebagai suatu auditory neuropathy yang disebabkan oleh faktor hiperbilirubinemia. Gejala klinis auditory neuropathy adalah gangguan pendengaran pada tingkat derajat ringan hingga berat, pada umumnya bilateral, hasil pemeriksaan OAE normal, kelainan pada pemeriksaan BERA, persepsi bicara yang buruk, serta tidak adanya refleks akustik. ${ }^{10}$

Dua pasien dengan hasil pemeriksaan OAE dan BERA awal dalam batas normal, tetapi pada pemeriksaan OAE kedua dengan hasil refer pada sisi unilateral dan BERA kedua menunjukkan gangguan pendengaran ringan. Hasil pemeriksaan ulangan menunjukkan perbaikan pada satu pasien dengan hasil OAE pass pada kedua telinga, sedangkan pasien yang lain tidak dapat kami hubungi. Perbaikan yang terjadi dapat berasal dari maturitas dan plastisitas jalur auditori mulai dari koklea berupa perubahan ukuran serta bentuk dari hair cell hingga maturitas fungsi sinap dan proses sentral auditori temporal otak yang ditunjukkan dengan perkembangan fungsi talamus-kortikal manusia. Plastisitas yang terjadi dapat dipengaruhi pula oleh stimulasi yang kronik maupun kompleks sehingga terjadi proses perbaikan pada sistem saraf pendengaran. ${ }^{11}$

Kelainan pada pemeriksaan OAE dan BERA ulangan menurut Holster $\mathrm{dkk}^{12}$ dapat disebabkan oleh karena tuli konduktif 20,3\%, tuli sensorineural 57,9\%, infeksi TORCH 1,8\%, genetik 13,3\%, dan penyebab yang tidak diketahui $42,9 \%$. Pasien tidak menunjukkan tanda infeksi TORCH klinis dan berdasarkan anamnesis tidak ditemukan anggota keluarga dengan riwayat gangguan pendengaran ataupun kelainan pada wajah. Lokasi yang menggambarkan gangguan pendengaran pada neonatus hiperbilirubinemia masih merupakan suatu hal kontroversial. Pengamatan morfologi menunjukkan gangguan pendengaran dapat terjadi pada jalur saraf, koklea maupun pada keduanya. Pada penelitian histopatologi ditemukan bahwa telinga bagian dalam dapat normal ataupun mengalami kerusakan yang berat. Pemeriksaan OAE dapat menilai kelainan yang terjadi pada outer hair cell koklea sebagai bagian dari telinga dalam. Oysu $\mathrm{dkk}^{13}$ menemukan keterlibatan kelainan koklea pada gangguan pendengaran karena hiperbilirubinemia memiliki insiden $13 \%$ berupa kelainan pada OAE meskipun pada pemeriksaan BERA tidak ditemukan kelainan. Boo $\mathrm{dkk}^{14}$ pada penelitian berikutnya mendukung pendapat bahwa hiperbilirubinemia dapat menimbulkan kerusakan pada koklea.

Risiko relatif kadar bilirubin indirek $\geq 12 \mathrm{mg} /$ $\mathrm{dl}$ terhadap kejadian gangguan pendengaran pada pemeriksaan BERA awal adalah 2. Ahlfors dan Parker 9 mengemukakan bahwa peningkatan kadar bilirubin indirek pada gangguan pendengaran bilateral lebih tinggi dibandingkan dengan tanpa gangguan pendengaran. Hasil tersebut tidak menjelaskan apakah peningkatan kadar bilirubin indirek untuk gangguan pendengaran unilateral berbeda atau tidak dibandingkan dengan tanpa gangguan pendengaran. Hasil yang sama ditunjukkan oleh Boo $\mathrm{dkk}^{8}$ yang mengemukakan bahwa gangguan pendengaran pada 
Gatot Irawan Sarosa dkk: Risiko gangguan pendengaran pada neonatus hiperbilirubinemia

neonatus dengan kadar bilirubin total $>20 \mathrm{mg} / \mathrm{dl}$ secara statistik tidak bermakna dibandingkan dengan neonatus dengan kadar bilirubin total $<20 \mathrm{mg} / \mathrm{dl}$. Juga ditemukan kadar bilirubin indirek yang tinggi hingga memerlukan tranfusi tukar serta usia saat timbulnya hiperbilirubinemia sebagai faktor risiko terjadinya gangguan pendengaran. Tata laksana yang tepat (fototerapi dan tranfusi tukar) serta kerentanan saraf auditori diduga mempengaruhi pengaruh toksin bilirubin terhadap saraf auditori. ${ }^{6,8}$

Keterbatasan penelitian ini, tidak melakukan pemeriksaan serial bilirubin terutama tidak selalu melakukan pemeriksaan kadar bilirubin setelah dilakukan terapi, tidak melakukan pemeriksaan bilirubin indirek bebas, tidak selalu dapat melakukan pemeriksaan OAE dan BERA sesegera mungkin pada saat pengambilan sampel darah pemeriksaan bilirubin dan tidak memeriksa TORCH karena keterbatasan dana, serta penanganan sesuai dengan protokol Bagian Perinatologi RSUP Dr Kariadi Semarang yang turut mempengaruhi hasil penelitian. ${ }^{15}$

\section{Kesimpulan}

Kejadian gangguan pendengaran pada neonatus dengan hiperbilirubinemia 25\%. Kadar bilirubin indirek $\geq 12 \mathrm{mg} / \mathrm{dL}$ belum dapat disimpulkan sebagai faktor risiko gangguan pendengaran pada neonatus dengan hiperbilirubinemia. Ditemukan pemeriksaan kadar bilirubin indirek bebas pada setiap neonatus dengan ikterik perlu dilakukan mengingat makin besarnya risiko gangguan pendengaran pada neonatus hiperbilirubinemia. Angka kejadian gangguan pendengaran pada neonatus hiperbilirubinemia masih tinggi, sehingga perlu dilakukan skrining gangguan pendengaran secara rutin sebelum pulang atau saat berusia tiga bulan.

\section{Daftar pustaka}

1. Suwento R. Gangguan pendengaran pada bayi dan anak. Dalam: Seminar Sehari Penatalaksanaan Gangguan Pendengaran dan Ketulian. Semarang; 2007. h.1-12.

2. World Health Organization: Situation review and update on deafness, hearing loss and intervention programmes: proposed plans of action for prevention and alleviation of hearing impairment in countries of the South-East Asia Region. 2007.

3. Rapin I. Hearing impairment. Dalam: Swaiman K.F, Ashwal S, penyunting. Pediatric Neurology Principles and Practice. Edisi ke-3. New York: Mosby Inc; 1999.h.77-95.

4. Cunningham M, Cox E O. Hearing assessment in infants and children: recommendations beyond neonatal screening. Pediatrics 2003; 111:436-40.

5. Mason JA, Herrmann KR. Universal infant hearing screening by automated auditory brainstem response measurement. Pediatrics 1998;101:221-8.

6. Sharma P, Chhangani N.P, Meena K.R, Jora R, Sharma N, Gupta B.D. Brainstem evoked response audiometry (BAER) in neonates with hyperbilirubinemia. Indian J Pediatr 2006;73:413-6.

7. Tioseco JA, Aly H, Milner J, Patel K, El-Mohandes AAE. Does gender affect neonatal hyperbilirubinemia in infants? Pediatr Crit Care Med 2005; 6: 171-4.

8. Boo NY, Oakes M, Lye MS, Said H. Risk factors associated with hearing loss in term neonates with hyperbilirubinaemia. J Trop Pediatr 1994;40:194- 7.

9. Ahlfors CE, Parker AE. Unbound bilirubin concentration is associated with abnormal automated auditory brainstem response for jaundiced newborns. Pediatrics 2008;121: 976-8.

10. Madden C, Rutter M, Hilbert L, Greinwald JH, Choo DI. Clinical and audiological features in auditory neuropathy, Arch Otolaryngol Head Neck Surg 2002;128:1026-30.

11. Fallon JB, Irvine DRF, Shepherd RK. Cochlear implants and brain plasticity. Hear res 2008;238:110-7.

12. Holster IR, Hoeve LJ, Wieringa MH, Willis-Lorrier RMS, Gier HHW. Evaluation of hearing loss after failed neonatal hearing screening. J Pediatr 2009;155:64650.

13. Oysu C, Ulubil A, Aslan I, Baserer N. Incidence of cochlear involvement in hyperbilirubinemic deafness. Ann Otol Rhinol Laryngol 2002;111:1021-4.

14. Boo NY, Rohani AJ, Asma A. detection of sensorineural hearing loss using automated auditory brainstem-evoked response and transient-evoked otoacustic emission in term neonates with severe hyperbilirubinemia.Singapore Med J 2008; 49:209-14.

15. Wennberg RP, Ahlfors CE, Bhutani VK, Johnson LH, Shapiro SM. Toward understanding kernicterus: a challenge to improve the management of jaundiced newborns. Pediatrics 2006;117;474-85. 